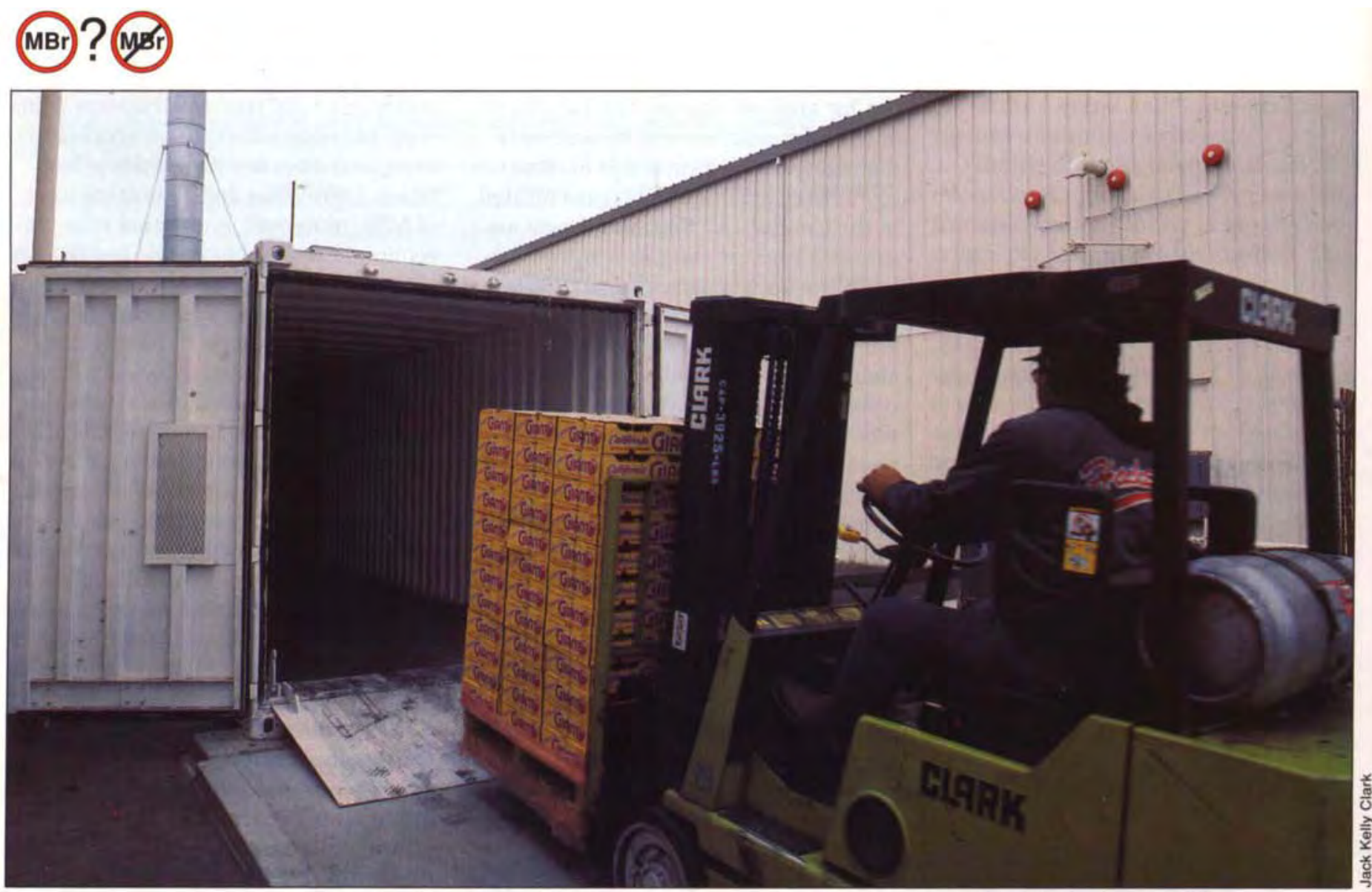

Although $95 \%$ of methyl bromide used in agriculture is for soil fumigation, postharvest applications of methyl bromide generate significantly higher returns per pound.

\title{
Cancelling methyl bromide for postharvest use to trigger mixed economic results
}

\section{Cherisa Yarkin $\square$ David Sunding}

The economic impacts of methyl bromide's (MBr) phaseout for postharvest fumigation vary widely among growers and, in the case of fumigation to meet quarantine restrictions, may vary widely from year to year. For walnuts, if processors use an alternative pest control strategy with a longer treatment time, a smaller supply of walnuts will be ready on November 1, a target date for shipping to Europe for the holidays. Cancellation of $\mathrm{MBr}$ could effectively eliminate access to export markets for cherries, peaches and nectarines until alternative quarantine treatments are approved by trade officials.

\section{口 David Zilberman $\square$ Jerry Siebert}

Routine fumigation of walnuts for export to Europe during the holiday season and fumigation of stone fruit and grapes to meet quarantine restrictions are two significant postharvest uses of methyl bromide in California. This article presents the results of models designed to measure the economic impacts of $\mathrm{MBr}$ cancellation for both of these postharvest applications. Minor uses of $\mathrm{MBr}$ not considered here include disinfestation treatments for other dried fruits and nuts and for commodities in long-term storage.

A companion project (see p. 10) analyzed the impacts of $\mathrm{MBr}$ for soil fumigation and found that economic losses are significant and concentrated in a few crops and regions. While soil fumigation is by far the most common application of $\mathrm{MBr}$ by California growers, accounting for $95 \%$ of all agricultural use in 1990, this article demonstrates that $\mathrm{MBr}$ is a valuable insect pest control agent for postharvest insect infestations as well. Indeed, postharvest applications of $\mathrm{MBr}$ are shown to generate significantly higher returns per pound than $\mathrm{MBr}$ used for soil fumigation.

The economic losses resulting from the loss of $\mathrm{MBr}$ for commodity fumigation have origins different from those for soil fumigation. While soil fumigation losses are mainly due to alternatives being more expensive, less effective or possibly both, losses from commodity fumigation applications of 
Right, roughly one-fourth of California's walnut crop is shipped to Europe to be sold around St. Nicholas' Day, which requires rapid processing in the tight time span between harvest and shipping. Phosphine is an alternative for fumigating in-shell walnuts, but its longer treatment time impedes timely marketing of the crop.

$\mathrm{MBr}$ are more complex. In the case of walnuts, which are fumigated primarily for control of codling moth and navel orangeworm, phosphine is in many respects an attractive alternative to $\mathrm{MBr}$, but has the significant disadvantages of a longer treatment time and reduced activity at low temperatures. Rapid processing and shipment of California walnuts are necessary to meet European holiday demand.

Roughly one-fourth of the crop is sold around St. Nicholas Day (December 7). The California crop rejected by Europe if $\mathrm{MBr}$ were not available would instead be sold on the lower-value domestic market. This article develops a dynamic model of the California walnut industry and applies that model to measure economic losses from the increased treatment time resulting from the switçh from $\mathrm{MBr}$ to phosphine.

The second type of postharvest impact occurs in the case of quarantine restrictions, which typically result from an exotic pest invasion. In this case, $\mathrm{MBr}$ treatment is currently required for some fresh fruits sold internationally. Examples include the five commodities considered in detail in this article: peaches, nectarines, sweet cherries, plums and grapes. Without changes in trade regulations, the loss of $\mathrm{MBr}$ could imply the loss of several important export markets in the event of a quarantine. Impact models that measure lost grower returns from selling otherwise exported fruit on the domestic market are described.

California growers may benefit from the fact that a number of imported fresh fruits have to be treated with $\mathrm{MBr}$ to comply with U.S. quarantine regulations. If foreign governments enforce a ban on $\mathrm{MBr}$ use in their countries, California producers will face less foreign competition and receive higher prices for their products as a result. This article describes the

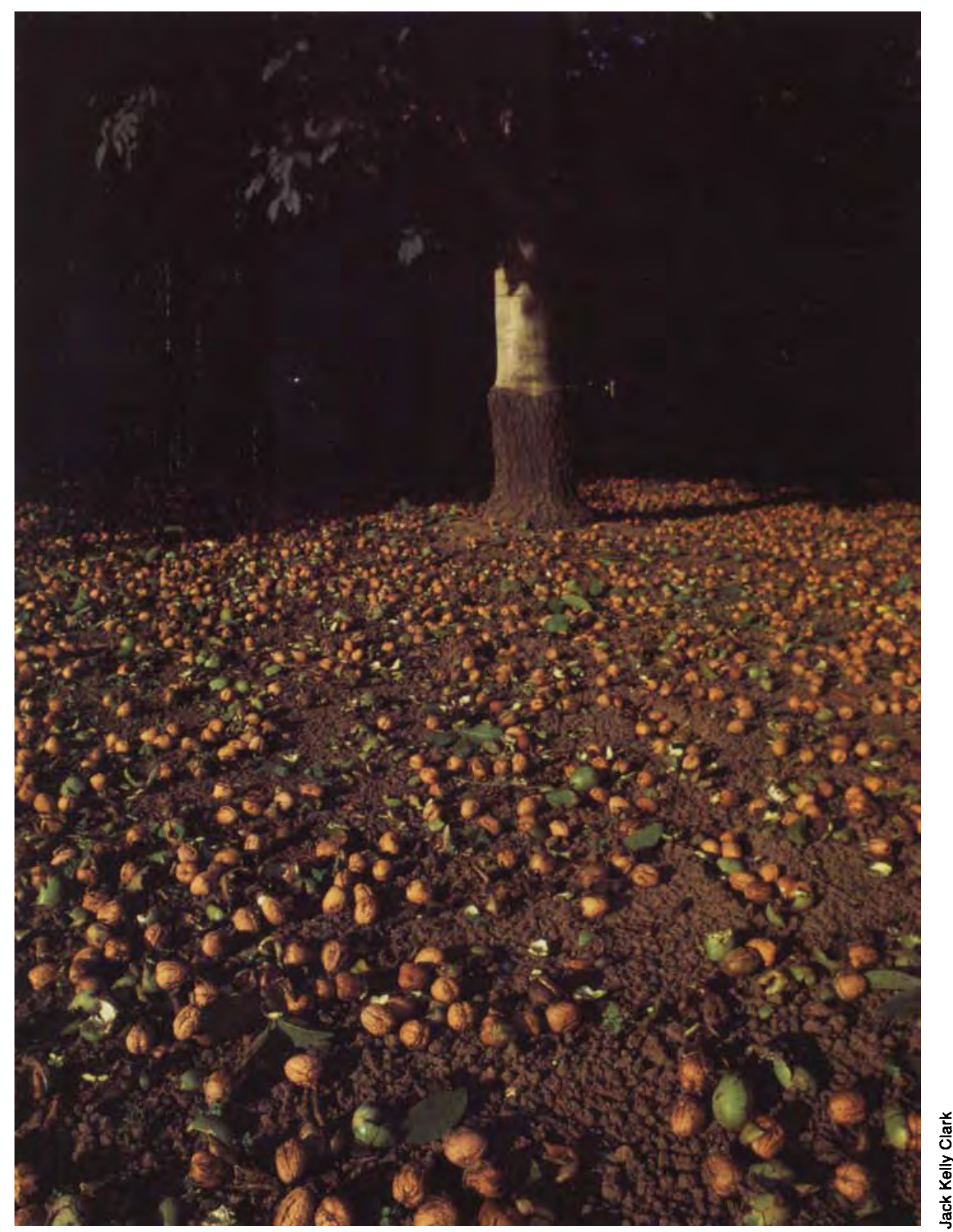

possible impacts of this phenomenon as well. If other countries do not enforce a ban, but the United States refuses to import commodities that have been treated with $\mathrm{MBr}$, the economic effects would be similar to those we have modeled.

\section{Impacts on walnuts}

California is the world's leading producer of walnuts, producing almost $100 \%$ of the U.S. commercial crop, or approximately $45 \%$ of the total world crop. Roughly one-third of the California walnut crop is exported. These exports constitute $75 \%$ of total in-shell shipments and $20 \%$ of shelled shipments. Walnuts were the 12 th most valuable export crop in California in 1992, with export revenues of over $\$ 136$ million.

There are two distinct markets for walnuts. The winter holiday market in Europe consists largely of in-shell walnuts. Walnuts sold in Europe currently must be treated with $\mathrm{MBr}$ as a condition of acceptance. The market for shelled nuts consists primarily of bakeries, cereal and snack food manufacturers and confectioners. This market has relatively constant year-round demand. Shelled product also constitutes a large export market.

The costs, attributes and regulatory status of current treatment options are shown in table 1 . MBr with recapture, 
phosphine, controlled atmospheres, cold or heat treatments and irradiation all require significant capital investment in new facilities. Heat treatments may damage walnuts, while cold and controlled atmospheres require lengthy exposure times. Given the geographical dispersion of walnut production in California, it is unlikely that establishment of a certified pestfree zone would be possible. While there are no biological controls currently available for use on walnuts, these techniques have long-term promise. Finally, researchers in Europe and Australia are developing systems for $\mathrm{MBr}$ recapture and reuse. While this technology is still in its infancy and may not be economically viable once it is fully developed, recap- ture could prove to be an acceptable alternative in the long term.

Given the currently available set of alternatives, walnut handlers facing immediate cancellation of $\mathrm{MBr}$ registration would most likely fumigate with phosphine. This alternative, widely used for fumigating other nuts, can be used in existing types of fumigation chambers, has a shorter exposure time than cold treatments and is currently less expensive than carbon dioxide and other controlled atmospheres. However, transition to phosphine implies an increase in treatment time from roughly four hours with $\mathrm{MBr}$ to up to one week. Fumigation chambers would probably have to be sealed tighter because of the long fumigation times required for phosphine fumigation.
A model of the economic impacts of $\mathrm{MBr}$ cancellation on the walnut industry must account for this additional treatment time. California walnut growers face strict shipping deadlines for sales to Europe: in-shell walnuts must be shipped by November 1 in order to reach the European market in time for traditional St. Nicholas Day celebrations. Because it is impossible to harvest walnuts earlier, at least in the short term, a major implication of the switch to phosphine is that the amount of California walnuts available for export to Europe will decline.

California growers produce a number of walnut varieties, not all of which are suitable for export. According to industry sources, foreign consumers have a strong preference for

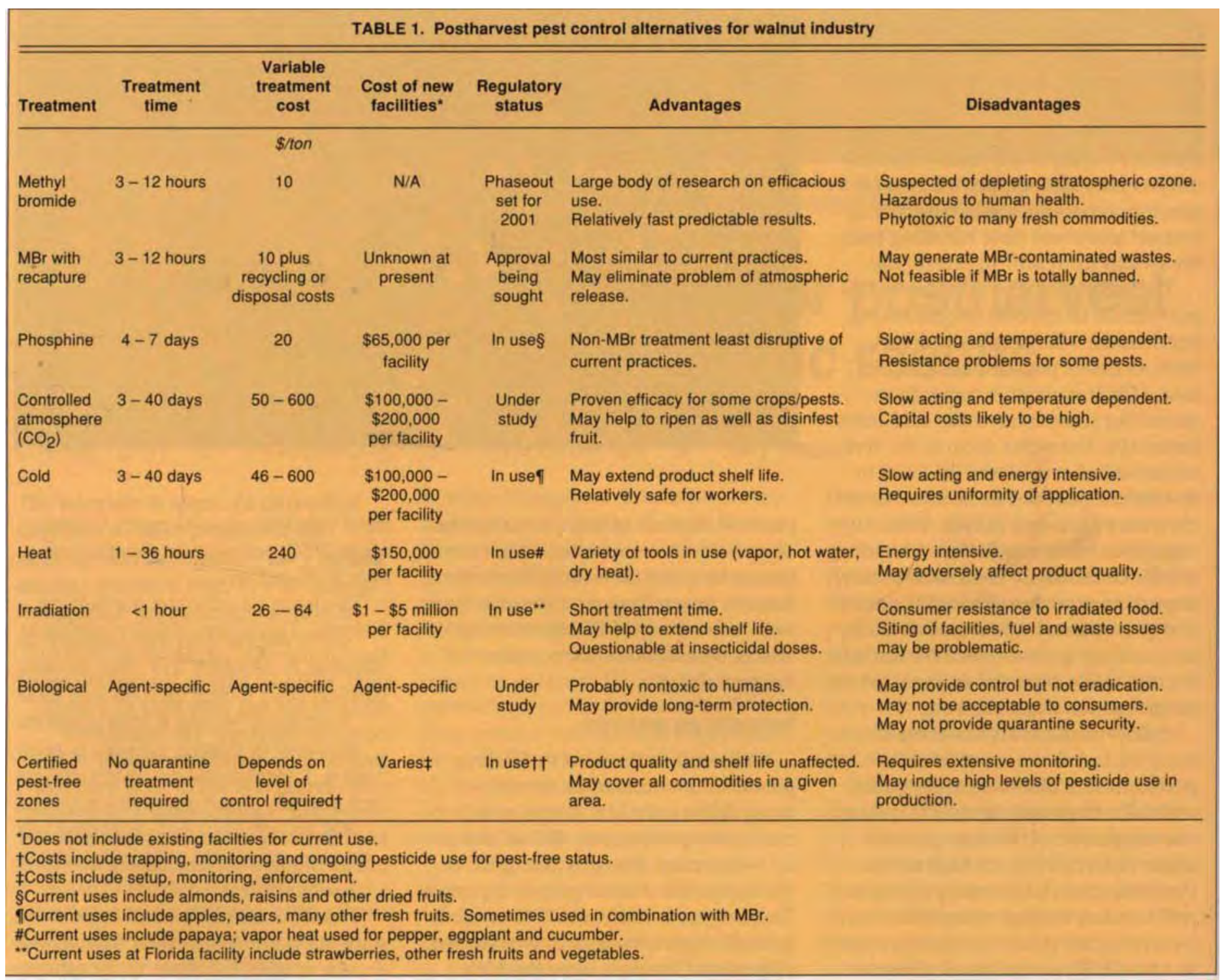


large walnuts with attractive appearance, and walnuts produced for domestic shelled consumption are not close substitutes. Because of their large size, export-quality walnuts are typically harvested later than walnuts destined for the shelled market. Figure 1 represents the harvest dates of exportable walnuts. Harvest lasts from the beginning of September to the beginning of December and peaks in midOctober. Line $A$ is drawn at October 31 , currently the last day growers can deliver walnuts to the processor for delivery to Europe. Export-quality walnuts not received by this date are sold in the domestic market. Line B is drawn one week earlier and corresponds to the cutoff date with phosphine fumigation. Approximately $9 \%$ of the total export-quality harvest occurs within this week.

Shifting California supply from the export to the domestic market may increase the export price if California suppliers have significant market power and decrease the domestic price. The economic impact of a oneweek change in the export cutoff date thus differs according to harvest date. Export-quality walnuts that are harvested earliest and are available for export even with the more restrictive shipping deadline generate higher returns due to higher export prices. Export-quality walnuts harvested later that would normally be exported but are sold on the domestic market when phosphine is used generate lower returns. In addition, walnuts that would normally be sold domestically generate lower returns as well due to the larger supply of nuts on the shelled market. There may thus be both gainers and losers among California walnut growers from the ban on $\mathrm{MBr}$ fumigation. The net effect on the industry as a whole depends on the relative responsiveness of consumer demand in the domestic and foreign markets to changes in the supply of walnuts.

The domestic demand elasticity is taken from a study of the California walnut industry completed at UC Davis. The elasticity of -0.32 estimated in this study indicates that the domestic walnut price is highly responsive to

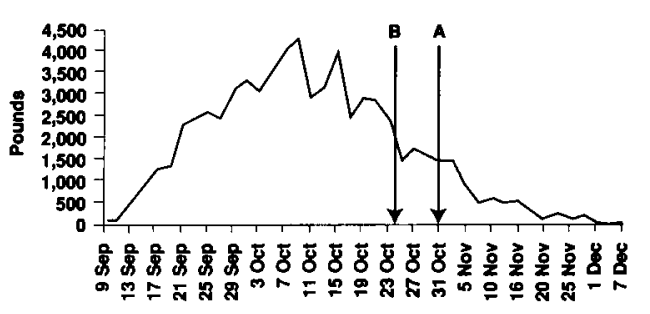

Fig. 1. Timing of export-quality walnut harvest.

changes in quantity and is consistent with results for other nuts and dried fruits. There is considerably more uncertainty regarding the export elasticity. A survey of industry experts, University of California economists and members of the California Walnut Board indicated a range of elasticity estimates from -0.20 to -0.70 . Accordingly, the impact model was run 100 times, with each run based on an export elasticity drawn randomly from this interval.

Economic impacts on California walnut growers of canceling $\mathrm{MBr}$ are shown in table 2. Total grower returns fall by $\$ 9.9$ million annually, or $2.8 \%$ of the total, as a result of the ban. Due to the uncertainty surrounding the export elasticity, the revenue impact has a standard deviation of $\$ 14.5$ million. As discussed above, the distribution of impacts differs by harvest date. Export-quality walnuts that are harvested earliest and are available for export even with the more restrictive shipping deadline earn $\$ 42.4$ million more in sales annually as a result of the ban. Export-quality walnuts that must be sold on the domestic market when phosphine is used generate $\$ 5.96$ million less revenue. Finally, walnuts previously sold on the domestic market produce $\$ 46.3$ million less revenue.

Note that this analysis applies only to revenues and does not account for the increased investment in fumigation capacity required to make the transition from $\mathrm{MBr}$ to phosphine fumigation. For some commodities, it is possible that demand in the time-constrained market is more price responsive than in the domestic market. In that case, the average price falls, and gains to early producers are not as great.

\section{Impacts involving quarantines}

California agricultural exports that have been subject to $\mathrm{MBr}$ fumigation as a quarantine measure are shown in table 3. Cherries exported to Japan and Korea and peaches and nectarines exported to Mexico require routine fumigation with $\mathrm{MBr}$ under current regulations, according to the National Agricultural Pesticide Impact Assessment Program of the USDA. California grapes and plums were subject to emergency quarantine in response to the 1980 Mediterranean fruit fly infestation. Not included in this analysis are minor crops such as kiwis and figs, crops that have readily available alternative treatments such as apples and tomatoes, and nonfood commodities such as cotton and oak logs for which differences in treatment duration are much less important.

In the short run, cancellation of $\mathrm{MBr}$ could effectively eliminate access to export markets for cherries, peaches and nectarines because use of alternative quarantine treatments would require formal trade negotiations. Since cherries, peaches and nectarines are highly perishable, any quarantine treatment requiring lengthy exposure times, such as controlled atmospheres or cold storage, would require modification of harvesting and handling practices to ensure that treated fruit is marketable. Estimated losses for commodities that are currently subject to quarantine are shown in table 3 . Estimated losses are determined by assuming that if $\mathrm{MBr}$ is banned, the entire crop would be sold in the domestic fresh market. Losses could be reduced by redirecting peaches, nectarines and cherries to other markets. Production and export data are from California Agriculture Statistical Review and California Agricultural Exports. Price elasticity estimates are from CARM (California Agricultural Resource Management model) and the USDA.

Table 3 also presents economic impacts for grapes and plums if an exotic pest infestation had occurred in 1992 and $\mathrm{MBr}$ fumigation had not been 
available. More than half of the estimated losses occur in the table grape industry, approximately $\$ 37$ million for a single year. As with peaches, nectarines and cherries, these losses could be reduced if growers were able to redirect table grapes to other markets. California plums are expected to experience the most severe price decline of the crops considered. Domestic plum prices are projected to fall by $30 \%$ if all production must be sold domestically. This large decrease occurs because the California plum industry produced
$87 \%$ of the U.S. commercial plum crop in 1992, and domestic plum demand is highly inelastic in that it is relatively unresponsive to changes in price. As a result, estimated losses for the plum industry are proportionally large, approximately $\$ 19$ million.

Quarantine treatment with $\mathrm{MBr}$ is not limited to exports of U.S. agricultural products. Agricultural imports that are subject to routine $\mathrm{MBr}$ fumigation as a quarantine measure are shown in table 4 . In most cases, these commodities are imported during pe-

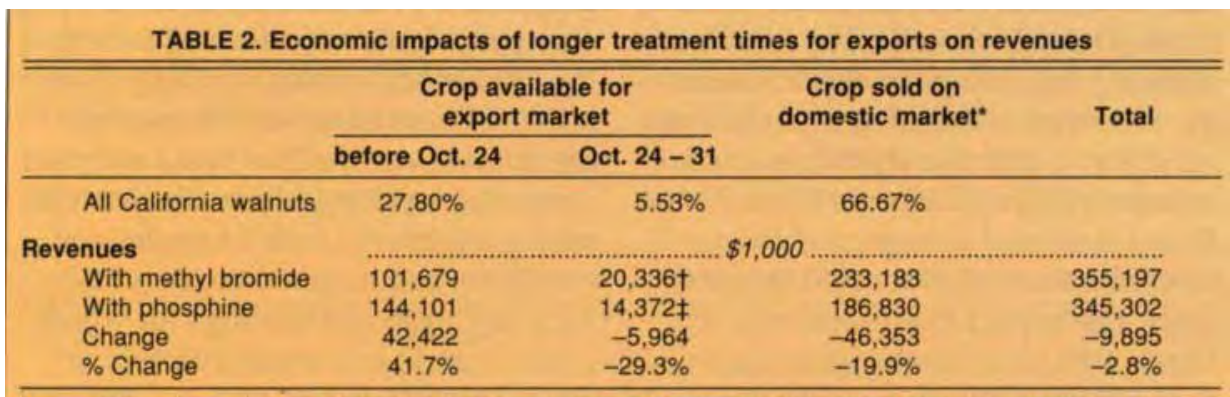

Notes: Harvest cutoff date is October 31 for export when fumigating with methyl bromide; cutoff date is October 24 when fumigating with phosphine.

Standard deviation of change in returns to early export quality wainuts is $\$ 14.5$ million. "All shelled product categorized as domestic sales for purpose of comparison.

tbased on export market prices because these walnuts meet the cutoff date for export.

fbased on domestic market prices because these walnuts miss the cutoff date for export.

TABLE 3. Impacts of methyl bromide cancellation on California exports subject to quarantine

\begin{tabular}{|c|c|c|c|c|c|c|}
\hline Crop & $\begin{array}{l}\text { California } \\
\text { production }\end{array}$ & $\begin{array}{l}\text { Share of total } \\
\text { U.S. production }\end{array}$ & $\begin{array}{c}\text { Sold } \\
\text { domestically }\end{array}$ & Exported & $\begin{array}{c}\text { Domestic } \\
\text { price change }\end{array}$ & $\begin{array}{c}\text { Change in } \\
\text { revenue }\end{array}$ \\
\hline & 1,000 tons & $\%$ & 1,000 tons & 1,000 tons & $\%$ & $\$ 1,000$ \\
\hline \multicolumn{7}{|l|}{ Current quarantine } \\
\hline Sweet cherries & 31 & 15 & 9 & 22 & -11 & $-4,231$ \\
\hline \multirow[t]{2}{*}{ Peaches \& nectarines } & 1,149 & 73 & 1,083 & 66 & -4 & $-11,600$ \\
\hline & & & & & Subtotal & $-15,832$ \\
\hline \multicolumn{7}{|l|}{ Potential quarantine } \\
\hline Table grapes & 645 & 90 & 457 & 188 & -16 & $-36,727$ \\
\hline \multirow[t]{2}{*}{ Plums } & 250 & 87 & 189 & 61 & -30 & $-19,020$ \\
\hline & & & & & $\begin{array}{l}\text { Subtotal } \\
\text { Total }\end{array}$ & $\begin{array}{l}-55,747 \\
-71,579\end{array}$ \\
\hline
\end{tabular}

Source: Calculated from data in California Agriculture Statistical Review 1992 and California Agricultural Exports 1992; elasticity estimates are from the CARM and USDA.

TABLE 4. Impacts from reduction in imported fruit

\begin{tabular}{|c|c|c|c|c|}
\hline Crop & $\begin{array}{l}\text { Months imported } \\
\text { into US }\end{array}$ & $\begin{array}{l}\text { Months produced } \\
\text { in California }\end{array}$ & $\begin{array}{l}\text { Imports treated } \\
\text { with } \mathrm{MBr}\end{array}$ & $\begin{array}{c}\text { Change in California } \\
\text { grower revenue }\end{array}$ \\
\hline & & & $\%$ & $\$ 1,000$ \\
\hline Apricots & Decernber - January & June - August & 90 & 0 \\
\hline Grapes & November - July & June - March & 92 & 35,874 \\
\hline \multirow{4}{*}{$\begin{array}{l}\text { Peaches/ } \\
\text { nectarines } \\
\text { Plums }\end{array}$} & & & & \\
\hline & November - April & April - November & 96 & 157 \\
\hline & January - May & May - December & 99 & 151 \\
\hline & & & & 36,181 \\
\hline
\end{tabular}

Source: USDA, USGAO, California Agriculture Statistical Review.

riods when California supplies are not available. For the purposes of this simulation, market quantity and price changes are calculated for the months in which California production competes directly with imported supplies under the assumption that no imports would occur. Demand elasticities are USDA estimates, and monthly import figures are taken from the Foreign $\mathrm{Ag}$ ricultural Trade of the United States bimonthly reports for 1992. Although consumers may suffer due to lack of availability of off-season fresh fruit during periods when neither California nor imported supplies are available, the nature and magnitude of those losses are beyond the scope of this article.

The months in which California competes directly with imports currently subject to quarantine treatment with $\mathrm{MBr}$ can be seen in table 4. Table grapes have the longest overlap period. The marketing season of California table grapes lasts from June through March; table grapes are imported from Chile and Mexico starting in November and continuing through July, with $92 \%$ of these imports requiring $\mathrm{MBr}$ fumigation. Estimated gains to California table grape producers are approximately $\$ 36$ million in the event that these imports are banned. Actual gains could be lower if competing producers in areas not subject to $\mathrm{MBr}$ quarantine treatments are able to increase supplies delivered to the U.S. market.

The gains to apricot producers from barring imports are minimal because apricots face almost no import competition in the fresh market. For California fresh peaches and nectarines, imports occur in months almost exactly complementary to those for domestic production and marketing. Direct competition occurs only at the beginning and end of the marketing season. Estimated gains for these producers are roughly $\$ 157,000$ annually. Similarly, California fresh plums have little overlap with imports except in the early part of the season, and estimated gains are of similar magnitude.

The impact on California producers of reduced imports of these commodities depends on the relationship between demand during the California 


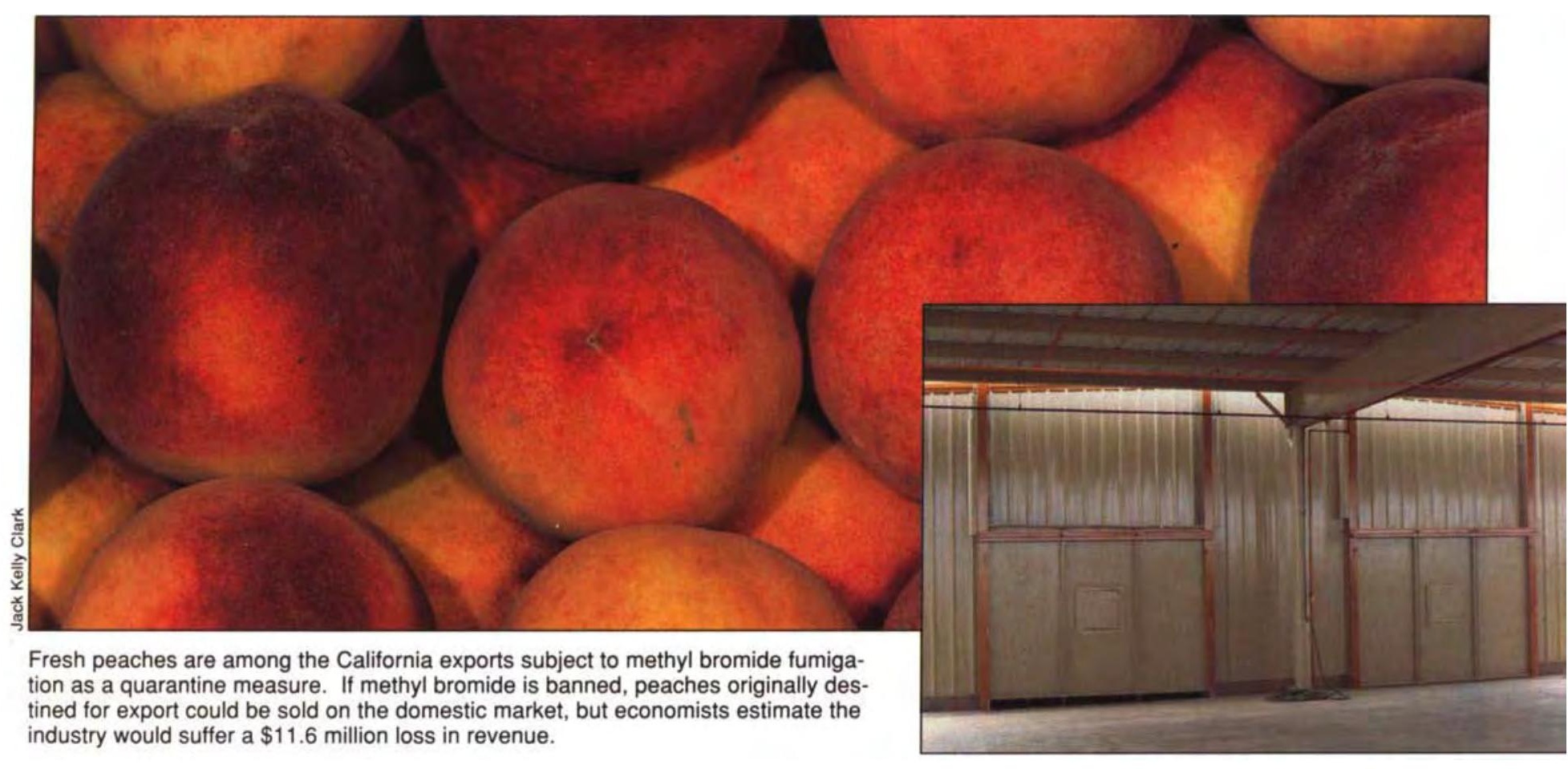

marketing season and off-season supplies. It has been argued in the case of red flame (also known as Flame Seedless) grapes, for instance, that demand for California table grapes marketed in the summer increased following the importation of Chilean red flame grapes during the winter months. Year-round availability of table grapes is supposed to have made them an "everyday" commodity like bananas, resulting in increased market shelf space and sales. If this anecdotal evidence is true, for grapes or other commodities, then California growers could actually suffer losses from a reduction in off-season imports.

\section{Long-run impacts}

The long-run impacts of the loss of $\mathrm{MBr}$ for commodity fumigation may differ substantially from the short-run impacts described above. Following cancellation of $\mathrm{MBr}$, the California walnut industry must find a way to cope with the time constraints of the holiday market. Programs to expand domestic or nonholiday export markets would ease this problem. Other long-run responses by the walnut industry to the loss of $\mathrm{MBr}$ include selecting varieties with earlier harvest dates or relocating orchards to warmer regions conducive to earlier harvest- ing. Because walnut trees take 7 to 10 years after planting to begin bearing economic yields, adjustments of this kind would take many years or perhaps decades to complete. More intensive research into alternative pest management techniques, especially biological controls, could yield acceptable alternative strategies that would be satisfactory replacements for $\mathrm{MBr}$ as a commodity protection treatment.

For commodities subject to current or potential quarantine restrictions, trade negotiations to remove the requirement for quarantine treatments or to approve alternative control techniques are ongoing. It is possible that as the deadline for an $\mathrm{MBr}$ ban approaches, progress will be made in these areas. There is some concern, however, that quarantine policies may be a means to protect importing countries' domestic producers as much from foreign competition as from exotic pests. If true, cancellation of $\mathrm{MBr}$ may result in a prolonged period in which California exports of walnuts and a variety of fresh fruits are reduced or, for some markets, completely eliminated.

Economic impacts on California growers would be exacerbated if growers in the state face a ban on $\mathrm{MBr}$ use that is not enforced on producers in other parts of the United States or the world. Such a regulation would put California agriculture at a competitive disadvantage, especially with respect to exports to Japan, Canada and Mexico. In this case, California producers lose export markets and returns when $\mathrm{MBr}$ is canceled, their foreign competitors who have access to $\mathrm{MBr}$ gain, and the environment remains compromised by continued use of $\mathrm{MBr}$. The costs to California growers of a ban on $\mathrm{MBr}$ will also be greater if state producers lose $\mathrm{MBr}$ ahead of the national or international schedule. This not only would force California producers to choose from a smaller set of alternatives than may be available later, but also would place them at a competitive disadvantage in world markets.

\section{Cherisa Yarkin is Graduate Student,}

David Sunding is Visiting Assistant Professor, David Zilberman is Professor, and Jerry Siebert is Economist at the Department of Agricultural and Resource Economics, UC Berkeley.

This research was supported by grants from the Office of Pesticide Consultation and Review, California Department of Food and Agriculture. The opinions expressed are those of the authors and not the State of California. 